\title{
Intercropping of young grapevines with native grasses for phytoremediation of $\mathrm{Cu}$-contaminated soils
}

\author{
Lessandro De Conti a, *, Carlos A. Ceretta ${ }^{b}$, George W.B. Melo ${ }^{c}$, Tadeu L. Tiecher ${ }^{\mathrm{d}}$, \\ Lincon O.S. Silva ${ }^{\mathrm{b}}$, Luana P. Garlet ${ }^{\mathrm{b}}$, Tanja Mimmo ${ }^{\mathrm{e}}$, Stefano Cesco ${ }^{\mathrm{e}}$, Gustavo Brunetto ${ }^{\mathrm{b}}$ \\ ${ }^{a}$ Federal Institute of Education, Science and Technology Farroupilha, 98590-000, Santo Augusto, RS, Brazil \\ b Department of Soil Science of the Federal University of Santa Maria, 97105-900, Santa Maria, RS, Brazil \\ ' Centro Nacional de Pesquisa de Uva e Vinho, Empresa Brasileira de Pesquisa Agropecuária (Embrapa), Bento Gonçalves, RS, Brazil \\ ${ }^{\mathrm{d}}$ Federal Institute of Education, Science and Technology Farroupilha, 97555-000, Alegrete, RS, Brazil \\ ${ }^{\text {e }}$ Faculty of Science and Technology, Free University of Bolzano, I-39100, Bolzano, Italy
}

\section{H I G H L I G H T S}

- Heavy metal phytoremediation of vineyards by native cover crops.

- Intercropping decrease $\mathrm{Cu}^{+2}$ in soil solution of Cu-contaminated soils.

- Native plants contribute to soil conservation and nutrient cycling in vineyards.

\section{A R T I C L E I N F O}

\section{Article history:}

Received 13 June 2018

Received in revised form

20 September 2018

Accepted 18 October 2018

Available online 19 October 2018

Handling Editor: T. Cutright

\section{Keywords:}

Copper availability

Vitis vinifera

Ionic speciation

Native plants

Heavy metal

\section{G R A P H I C A L A B S T R A C T}

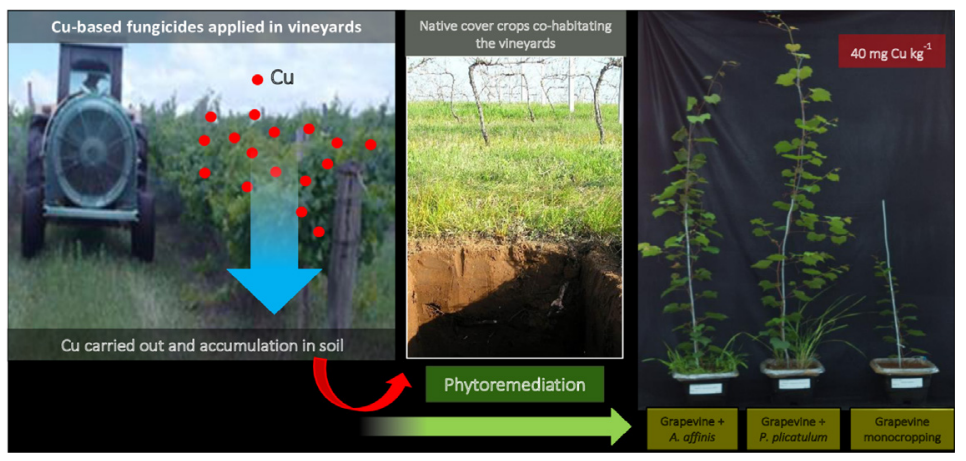

\footnotetext{
* Corresponding author.

E-mail address: lessandrodeconti@gmail.com (L. De Conti).
} 
soils and obtaining a grape production system with reduced interventions in the native environment, in addition to contributing to soil protection and nutrient cycling.

() 2018 Elsevier Ltd. All rights reserved.

\section{Introduction}

It is well known that human activities, especially in the agricultural context, have caused heavy metal accumulation in the environment, giving rise to soil pollution in different parts of the world (Ali et al., 2013; De Conti et al., 2016; Leguizamo et al., 2017; Wan et al., 2017). In this respect, one example is represented by the application of copper(Cu)-based fungicides aimed at controlling pest disease in orchards and vineyards, particularly problematic in regions with frequent rainfall and high temperatures during the growing cycle of the plant (Komárek et al., 2010; Miotto et al., 2014; Cambrollé et al., 2015; Baldi et al., 2018). Therefore, it is very common to find soils characterized by very high $\mathrm{Cu}$ content (Brunetto et al., 2016) with evident impacts on crop performance. In fact, $\mathrm{Cu}$ is an essential element for important metabolic processes in plants (Marschner, 2011), but when high concentrations of the ionic form are present in the soil solution, excess $\mathrm{Cu}$ uptake may occur, inducing toxicity symptoms in crops. The consequences are reduced crop growth, limited yield and quality, changes in root morphology and nutritional imbalance (Yruela, 2005; Cambrollé et al., 2015; Oustriere et al., 2016). These phenomena (i.e. metal accumulation in soil and toxicity to plants) are well described for both vineyard soils and grapevines. However, it is interesting to note that other plants co-habitating these soils suffer from the same nutritional disorder with very similar symptoms (Ambrosini et al., 2015; Girotto et al., 2016; Tiecher et al., 2016). From an agricultural point of view, this problem is even worse when replanting new grapevines, which limits the success for renewing a vineyard (Miotto et al., 2014; Brunetto et al., 2016; Baldi et al., 2018). For this reason, where the problem is already present, from a medium to a long-term perspective that still guarantees grapevine cultivation in these areas used for viticulture, the need to set agronomic practices limiting $\mathrm{Cu}$ availability in soil is urgent (Brunetto et al., 2016). Certainly, all the agronomic measures limiting the use of Cu-based agrochemicals for plant defense programs can prevent further worsening of the problem.

In the recent decades, the expansion of viticulture in the state of Rio Grande do Sul, currently responsible for $90 \%$ of Brazil's wine production (Flores and Medeiros, 2013), has occurred mainly on natural grasslands (of the Pampa Biome) in southern Brazil as well as in Uruguay and Argentina. Plants native to the Pampa Biome are spontaneously found in vineyards of this region and are managed as cover crops by periodic mowing. Botanical investigations conducted in these areas have shown the presence of about 3000 plant species, with a remarkable diversity of grasses (more than 450 species) (Brasil, 2017). Within these grass species, Axonopus affinis and Paspalum plicatulum are the most ubiquitous native plant species (Quadros et al., 2009). It is interesting to note that both species evolved in acidic and chemically poor-soils and possess adaptive mechanisms to optimize nutrient acquisition processes and to limit the effects of aluminum $\left(\mathrm{Al}^{3+}\right)$ toxicity (Pallarés et al., 2005). The adaptability to local conditions and the spontaneous occurrence of these native grasses indicate a high potential for lowcost phytoremediation approach (Leguizamo et al., 2017).

Studies have shown that features ( $\mathrm{pH}$, humidity, redox state, microbial community, etc.) of the soil surrounding the roots (i.e. rhizosphere) can be greatly modified by root activity as a consequence of several different environmental conditions such as nutrient deficiency or toxicity (Hinsinger et al., 2009; De Conti et al., 2018). In this respect, roots release a plethora of exudates (e.g. protons, soluble organic compounds such as organic acids, amino acids, phenolic compounds). Due to their impact on $\mathrm{pH}$ and their metal-complexing properties (thus named ligands), they also considerably affect nutrient availability for plant uptake (Chaignon et al., 2009; Dresler et al., 2014; Mimmo et al., 2014; De Conti et al., 2016; Chen et al., 2017). With respect to Cu and particularly when its concentration in soil is high, it has been hypothesized that the $\mathrm{Cu}$ complexation process mediated by these ligands released by roots and at the expense of the ionic $\left(\mathrm{Cu}^{+2}\right)$ pool used by plants and microorganisms (McBride, 1994; Kabata-Pendias, 2011) could limit the extent of the metal acquisition by roots. In other words, this root-mediated phenomenon can be considered as an attempt by the plant to stabilize the metal outside the root, limiting thus its availability and, in turn, its plant uptake (De Conti et al., 2018). It is interesting to note that when this mechanism occurs in the rhizosphere of mixed roots of two intercropped plant species (one tolerant and another intolerant), both species can benefit from it (Brunetto et al., 2016; Wan et al., 2017), regardless of the relative contribution on metal stabilization. In fact, the agronomic practice of intercropping is hypothesized to be a valid phytoremediation approach for soils slightly or moderately contaminated with heavy metals (Wan et al., 2016). In particular for the case of $\mathrm{Cu}$, the functionality of adaptive mechanisms to $\mathrm{Al}^{3+}$ toxicity in Axonopus affinis and Paspalum plicatulum makes them particularly interesting (Sainger et al., 2011; Leguizamo et al., 2017). In addition, intercropping to control and limit $\mathrm{Cu}$ availability in soils would not only guarantee grapevine cultivation in vocated areas (Wan et al., 2017), but also the achievement of quality parameters intrinsically linked to the cultivation environment such as the viticulture terroir (Muscas et al., 2017). Thus, evaluating the capacity of native grasses and intercropping in reducing $\mathrm{Cu}$ toxicity in grapevines is fundamental for the establishment of phytoremediation strategies in vineyards contaminated with $\mathrm{Cu}$.

Based on these premises, this study aimed to evaluate the contribution of native grass species in limiting $\mathrm{Cu}$ availability in soil cultivated with grapevines. For this purpose, plants of the Paulsen 1103 rootstock (Vitis vinifera $\mathrm{cv}$.) were grown in monocropping and intercropping with Axonopus affinis or Paspalum plicatulum in pots containing Typic Hapludalf soil. In order to mimic the soil contamination via $\mathrm{Cu}$-based agrochemicals after 15 or 30 years of applications, two batches of soil were contaminated with 40 or $80 \mathrm{mg} \mathrm{kg}^{-1} \mathrm{Cu}$, respectively. The results of the analysis of soil solution and plant tissues are discussed in terms of redistribution of copper among soil fractions and its impact on plant health.

\section{Material and methods}

\subsection{Soils}

The study was carried out using a Typic Hapludalf soil (Soil Survey Staff, 2006) collected at $0-20 \mathrm{~cm}$ in an area of uncultivated native grassland ( $30^{\circ} 47^{\prime} 23.7^{\prime \prime} \mathrm{S}$ and $\left.55^{\circ} 22^{\prime} 7.3^{\prime \prime} \mathrm{W}\right)$ with naturally low $\mathrm{Cu}$ content. Table 1 shows soil physical and chemical characteristics. The area is located in the Campanha Gaúcha region, 
Table 1

Physical and chemical characteristics of the $0.0-0.20$ m layer in a Typic Hapludalf soil under natural grassland.

\begin{tabular}{|c|c|}
\hline & Natural grassland \\
\hline Clay $\left(\mathrm{g} \mathrm{kg}^{-1}\right)$ & 54 \\
\hline Sand $\left(\mathrm{g} \mathrm{kg}^{-1}\right)$ & 894 \\
\hline Silt $\left(\mathrm{g} \mathrm{kg}^{-1}\right)$ & 52 \\
\hline Organic matter $\left(\mathrm{g} \mathrm{kg}^{-1}\right)$ & 9.0 \\
\hline $\mathrm{pH}_{\mathrm{H} 2 \mathrm{O}}(1: 1)$ & 5.2 \\
\hline Exchangeable $\mathrm{Al}\left(\mathrm{mg} \mathrm{kg}^{-1}\right)$ & 0.4 \\
\hline Available $\mathrm{Cu}$ by EDTA $\left(\mathrm{mg} \mathrm{kg}^{-1}\right)$ & 0.7 \\
\hline Available $\mathrm{Zn}$ by EDTA (mg kg-1) & 0.9 \\
\hline Available K by Mehlich-1 (mg kg$\left.{ }^{-1}\right)$ & 66.4 \\
\hline Available P by Mehlich-1 (mg kg $\left.{ }^{-1}\right)$ & 3.6 \\
\hline Available Fe by EDTA ( $\mathrm{mg} \mathrm{kg}^{-1}$ ) & 5.9 \\
\hline Available Mn by EDTA ( $\mathrm{mg} \mathrm{kg}^{-1}$ ) & 15.4 \\
\hline Exchangeable $\mathrm{Ca}\left(\mathrm{mg} \mathrm{kg}^{-1}\right)$ & 0.5 \\
\hline Exchangeable $\mathrm{Mg}\left(\mathrm{mg} \mathrm{kg}^{-1}\right)$ & 0.2 \\
\hline $\mathrm{CEC}_{\mathrm{ef}}{ }^{\mathrm{a}}, \mathrm{cmol}_{\mathrm{c}} \mathrm{kg}^{-1}$ & 1.4 \\
\hline $\mathrm{CEC}_{\mathrm{pH}} 7.0^{\mathrm{b}}, \mathrm{cmol}_{\mathrm{c}} \mathrm{kg}^{-1}$ & 3.2 \\
\hline
\end{tabular}

${ }^{\text {a }} \mathrm{CEC}_{\mathrm{ef}}=$ Ability to effectively exchange cations.

b $\mathrm{CEC}_{\mathrm{pH}} 7.0=$ Cation exchange capacity at $\mathrm{pH}$ 7.0.

city of Santana do Livramento, state of Rio Grande do Sul, which is part of the Pampa Biome in southern Brazil. After collection, the soil was air-dried, homogenized and passed through a $2 \mathrm{~mm}$ mesh sieve. Soil $\mathrm{pH}$ was adjusted by adding a mixture of calcium carbonate $\left(\mathrm{CaCO}_{3}\right)$ and magnesium carbonate $\left(\mathrm{MgCO}_{3}\right)$, with a ratio of $2: 1$, at a dose of $0.57 \mathrm{~g} \mathrm{~kg}^{-1}$ of soil. The soil was then incubated at $80 \%$ of the maximum water holding capacity (MWHC) for 35 days. Afterwards, we applied $40 \mathrm{mg} \mathrm{P} \mathrm{kg}^{-1}$ and $100 \mathrm{mg} \mathrm{kg}^{-1} \mathrm{~K}$ of soil by adding triple superphosphate and potassium chloride, respectively. Soil moisture was restored to $80 \%$ of the MWHC and incubation continued for another 25 days. This soil was the control soil (dose 0 ), representative of the condition prior to the installation of the vineyards. This soil was further spiked either with 40 and $80 \mathrm{mg} \mathrm{kg}^{-1} \mathrm{Cu}$ (dose 40 and 80 ), which are levels typically found in vineyards under grapevine cultivation of approximately 15 and 30 years, respectively (Miotto et al., 2014). In sandy acidic soils used to cultivate grapevines in this region of the study, approximately $80 \%$ of total $\mathrm{Cu}$ accumulated in these soils is potentially available to plants and may cause phytotoxicity even at low total soil levels (Miotto et al., 2017). The addition of Cu occurred 50 days after the application of the corrective, by applying a solution of $\mathrm{CuSO}_{4} 5 \mathrm{H}_{2} \mathrm{O}$ (PA reagent, Vetec). Subsequently, the soil was incubated again for 115 days under the same conditions described above. Every step of soil incubation was done in a greenhouse, where the temperature was kept at $25 \pm 5^{\circ} \mathrm{C}$. Soil moisture content was measured three times a week (by weighing) throughout the incubation period; distilled water was added when necessary to replenish the evaporated water and maintain the MWHC at $80 \%$.

\subsection{Experimental design and crops}

The experiment was conducted in greenhouse. During the experimental period, temperature was kept at $25 \pm 5^{\circ} \mathrm{C}$, relative humidity was approximately $70 \%$, and there was no interference in the photoperiod (natural conditions). The experimental design was completely randomized with three replicates per each treatment, totaling 27 experimental units ( 3 Cu doses $\times 3$ cropping treatments $\mathrm{x} 3$ replicates). The experimental units consisted of pots containing $7 \mathrm{~kg}$ of soil. At each $\mathrm{Cu}$ dose, grapevine was grown in cropping treatments: monocropping (Grapevine), intercropping with Paspalum plicatulum (Grapevine + Paspalum plicatulum) and intercropping with Axonopus affinis (Grapevine + Axonopus affinis) (Fig. 1). In November, we transplanted one grapevine (Vitis vinifera
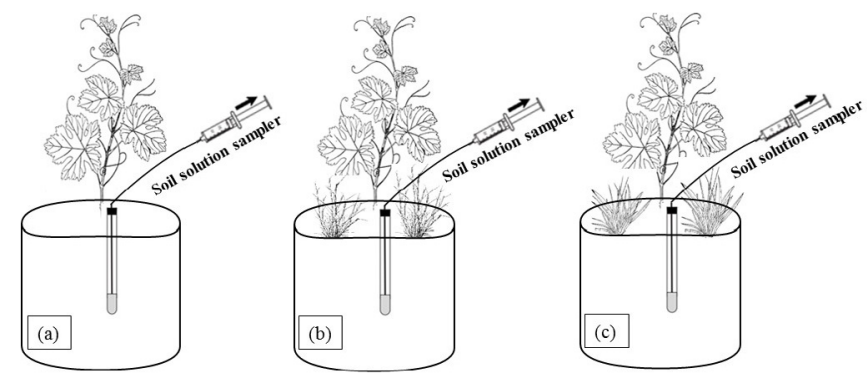

Fig. 1. Schematic representation of the experimental units. Grapevines grown in monocropping (a), intercropping with Paspalum plicatulum (b) and intercropping with Axonopus affinis (c). Rhizon samplers were set near the grapevine.

cv. Berlandieri Resseguier $\mathrm{n}^{\circ} 2$ x Rupestris de Lot) plant per pot, where it was grown for 70 days. In treatments with intercropping, the two South American native grasses were transplanted into each pot, 35 days prior to the transplanting of the grapevines. Grapevine plants were obtained by in vitro multiplication of bud explants, with rooting in sterile substrate (Kyte et al., 2013). Explants were grown for 30 days in a growth room at a temperature of $25 \pm 1^{\circ} \mathrm{C}$, photoperiod of $16 \mathrm{~h}$ daylight and photosynthetically active radiation of $75 \mu \mathrm{mol}$ photons $\mathrm{m}^{-2} \mathrm{~s}^{-1}$. The plants were subsequently transferred into $200 \mathrm{~mL}$ plastic pots containing horticultural substrate and thin vermiculite (1:1 ratio) and grown for another 30 days in a growth room. Later, a plantlet of approximately $20 \mathrm{~cm}$ in height was transferred to a greenhouse for another 15 days and kept with $50 \%$ interference of the radiation, for the future installation of the experiment.

The native grasses were collected in natural grassland and multiplied by means of preculture with nutrient solution in sand to obtain uniform seedlings of about $12 \mathrm{~cm}$ in height. The cultivation of the native grasses was carried out in a greenhouse. During the growing period, temperature was kept at $25 \pm 5^{\circ} \mathrm{C}$, relative humidity was approximately $70 \%$, and there was no interference in the photoperiod (natural conditions). The complete nutrient solution used to irrigate the plants in preculture consisted of $\left(\mathrm{mg} \mathrm{L}^{-1}\right)$ : $149.80 \mathrm{NO}_{3}^{-} ; 24.80 \mathrm{H}_{2} \mathrm{PO}_{4}^{-} ; 39.27 \mathrm{SO}_{4}^{2-} ; 41.31 \mathrm{Mg}^{2+} ; 288.72 \mathrm{Ca}^{2+}$; $234.60 \mathrm{~K}^{+}$; $0.03 \mathrm{Mo}$; 0.26 B; $0.06 \mathrm{Cu} ; 0.50 \mathrm{Mn} ; 0.22 \mathrm{Zn}$; and $4 \mathrm{Fe}$, supplied through irrigation three times a day.

At the time of transplanting of the grapevines and native grasses, the preculture substrate was carefully removed by washing with distilled water. At 16 and 48 days after transplanting, nitrogen (N) was applied as urea (20 and $10 \mathrm{mg} \mathrm{N} \mathrm{kg}^{-1}$ of soil, respectively). In the intercropping treatments, the shoots of the cover crops were cut at $10 \mathrm{~cm}$ (height) and placed on the soil surface every 21 days, totaling three cuts throughout the grapevine cultivation period. This cover crop management aims to simulate mowing used in commercial vineyards.

\subsection{Extraction, analysis and speciation of the soil solution}

Soil solution was extracted the day prior to the transplanting (1st sampling) and 69 (2nd sampling) days after transplanting using Rhizon MOM mini-lysimeter. The Rhizon MOM samplers were installed in the soil at a depth of 2-12 cm (Fig. 1). Soil moisture was maintained at $70 \%$ MWHC during cultivation with daily weightings and addition of distilled water to replenish the evaporated water and maintain soil moisture. The day prior to the extraction of the soil solution, moisture was raised to $95 \%$ MWHC to facilitate the extraction of the soil solution. The solution was sampled $16 \mathrm{~h}$ after irrigation by creating a vacuum with the use of a $60 \mathrm{~mL}$ syringe. Afterwards, we measured $\mathrm{pH}$ and dissolved organic carbon (DOC) 
Table 2

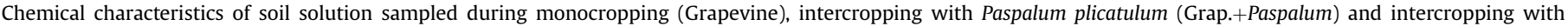
Axonopus affinis (Grap.+Axonopus) in soils with increasing Cu levels.

\begin{tabular}{|c|c|c|c|c|}
\hline \multirow[t]{2}{*}{ Solution chemical parameters } & \multirow{2}{*}{$\frac{\text { Cu doses }}{\left(\mathrm{mg} \mathrm{kg}^{-1}\right)}$} & \multicolumn{3}{|c|}{ Cropping treatments } \\
\hline & & Grapevine & Grap.+Paspalum & Grap.+Axonopus \\
\hline & & 1st Samplin & & \\
\hline \multirow[t]{3}{*}{$\mathrm{pH}$} & 0 & $6.01 \mathrm{aB}^{1}$ & $6.63 \mathrm{aA}$ & $6.07 \mathrm{aB}$ \\
\hline & 40 & $5.33 \mathrm{bC}$ & $6.45 \mathrm{aA}$ & $5.85 \mathrm{aB}$ \\
\hline & 80 & $5.30 \mathrm{bA}$ & $5.67 \mathrm{bA}$ & $5.53 \mathrm{bA}$ \\
\hline \multirow[t]{3}{*}{ Dissolved organic carbon $\left(\mathrm{mg} \mathrm{L}^{-1}\right)$} & 0 & $11.00 \mathrm{bB}$ & $17.00 \mathrm{aA}$ & $12.00 \mathrm{aB}$ \\
\hline & 40 & $15.33 \mathrm{aB}$ & $18.67 \mathrm{aA}$ & $13.00 \mathrm{aB}$ \\
\hline & 80 & $14.33 \mathrm{aB}$ & $16.33 \mathrm{aA}$ & $13.33 \mathrm{aB}$ \\
\hline \multirow[t]{4}{*}{ Soluble $\mathrm{Cu}\left(\mathrm{mg} \mathrm{L}^{-1}\right)$} & 0 & $0.018 \mathrm{cA}$ & $0.021 \mathrm{cA}$ & $0.015 \mathrm{cA}$ \\
\hline & 40 & $0.290 \mathrm{bB}$ & $0.422 \mathrm{bA}$ & $0.330 \mathrm{bB}$ \\
\hline & 80 & $0.780 \mathrm{aA}$ & $0.757 \mathrm{aA}$ & $0.773 \mathrm{aA}$ \\
\hline & & 2nd Sampli & & \\
\hline \multirow[t]{3}{*}{$\mathrm{pH}$} & 0 & $6.31 \mathrm{aC}$ & $7.30 \mathrm{aA}$ & $6.79 \mathrm{aB}$ \\
\hline & 40 & $5.23 \mathrm{bB}$ & $6.68 \mathrm{bA}$ & $6.57 \mathrm{aA}$ \\
\hline & 80 & $5.47 \mathrm{bB}$ & $6.23 \mathrm{cA}$ & $5.49 \mathrm{bB}$ \\
\hline \multirow[t]{3}{*}{ Dissolved organic carbon $\left(\mathrm{mg} \mathrm{L}^{-1}\right)$} & 0 & $17.67 \mathrm{aA}$ & $20.00 \mathrm{bA}$ & $19.00 \mathrm{aA}$ \\
\hline & 40 & $12.67 \mathrm{bC}$ & $24.33 \mathrm{aA}$ & $18.67 \mathrm{aB}$ \\
\hline & 80 & 9.67 bB & $12.33 \mathrm{cB}$ & $15.33 \mathrm{bA}$ \\
\hline \multirow[t]{3}{*}{ Soluble $\mathrm{Cu}\left(\mathrm{mg} \mathrm{L}^{-1}\right)$} & 0 & $0.019 \mathrm{cA}$ & $0.021 \mathrm{cA}$ & $0.024 \mathrm{cA}$ \\
\hline & 40 & $0.338 \mathrm{bA}$ & $0.352 \mathrm{bA}$ & $0.353 \mathrm{bA}$ \\
\hline & 80 & $1.039 \mathrm{aB}$ & $0.808 \mathrm{aC}$ & $1.512 \mathrm{aA}$ \\
\hline
\end{tabular}

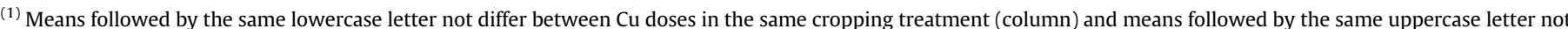
differ between the cropping treatments at the same $\mathrm{Cu}$ dose (row) by the Scott-Knott test ( $\mathrm{p}<0.05$ ).

content spectrophotometrically at $560 \mathrm{~nm}$ after digestion with $0.4 \mathrm{~N}$ potassium dichromate at $60^{\circ} \mathrm{C}$ for $4 \mathrm{~h}$ as described by Silva and Bohnen (2001). In the soil solution of the sampled, contents of aluminum $(\mathrm{Al})$, calcium $(\mathrm{Ca})$, magnesium $(\mathrm{Mg})$, copper $(\mathrm{Cu})$, zinc $(\mathrm{Zn})$, manganese $(\mathrm{Mn})$, potassium $(\mathrm{K})$, iron $(\mathrm{Fe})$ and phosphorus $(\mathrm{P})$ were determined by inductively coupled plasma atomic emission spectroscopy (ICP Perkin-Elmer, USA); ammonium $\left(\mathrm{NH}_{4}^{+}\right)$and nitrate $\left(\mathrm{NO}_{3}^{-}\right)$were determined by colorimetry at $660 \mathrm{~nm}\left(\mathrm{NH}_{4}^{+}\right)$and $540 \mathrm{~nm}\left(\mathrm{NO}_{3}^{-}\right)$(SANplus, Skalar, Breda, Holand); and sulfur (S) and chlorine $(\mathrm{Cl})$ were determined by ion chromatography (S135 Ion Chromatography system, Germany) (Table 2).

Ionic speciation of the solution was determined by Visual Minteq software (version 3.0 - Gustafsson, 2013) using the total soluble cations $\left(\mathrm{Al}^{3+}, \mathrm{Ca}^{2+}, \mathrm{Mg}^{2+}, \mathrm{Zn}^{2+}, \mathrm{Cu}^{2+}, \mathrm{Mn}^{2+}, \mathrm{K}^{+}\right.$and $\left.\mathrm{Fe}^{2+}\right)$, anions $\left(\mathrm{PO}_{4}^{3-}, \mathrm{NO}_{3}^{-}, \mathrm{SO}_{4}^{-2}\right.$ and $\left.\mathrm{Cl}^{-}\right), \mathrm{DOC}$ and $\mathrm{pH}$ of the soil $(\mathrm{n}=3)$. The formation of metal complexes with DOC was evaluated using Gaussian DOM model (Grimm et al., 1991). The formation of inorganic soluble complexes was assessed using the standard equilibrium constants of the Visual Minteq software developed by Smith et al. (2003). We thereby obtained the percentage distribution of all species of $\mathrm{Cu}$ in the soil solution.

\subsection{Dry matter yield and nutrient analysis in plant tissue}

At 70 days after the transplanting of the grapevines, the shoots were cut close to the soil surface; the leaves were separated from the branches and stored for the determination of dry matter (DM) yield and nutrient analysis. The roots were separated from the soil by hand, washed in running tap water to remove soil particles, dried with paper and then weighed. Afterwards, the root system was divided into two portions: one was placed in distilled water for future assessment of the root architecture, while the second portion was washed in $0.02 \mathrm{~mol} \mathrm{~L}^{-1}$ EDTA solution to remove nutrients outside the roots, according to the procedure described by Miotto et al. (2014); and washed with distilled water three times for subsequent determination of DM yield and nutrient concentration. Leaves, stem and roots were then dried in an oven with forced air at $\pm 65^{\circ} \mathrm{C}$ until reaching constant weight to assess DM yield.
Dried leaves, stem and roots were ground in a Wiley mill and digested with $\mathrm{HNO}_{3}-\mathrm{HClO}_{4}$ (Embrapa, 1997) to determine the concentration of $\mathrm{Cu}, \mathrm{Fe}, \mathrm{Mn}$ and $\mathrm{P}$. Cations were determined by atomic absorption spectrophotometer (AAS) and P by colorimetry (Murphy and Riley, 1962).

\subsection{Root architecture}

The morphological characterization of the roots was obtained by scanned images, using WinRhizo Pro 2013 software, coupled to an EPSON Expression 11000 scanner equipped with additional light (TPU), with a definition of $600 \mathrm{dpi}$. We determined total root length $(\mathrm{cm})$, surface area $\left(\mathrm{cm}^{2}\right)$, volume $\left(\mathrm{cm}^{3}\right)$ and average diameter $(\mathrm{mm})$. The root system was grouped into five diameter classes: $0-0.2$; $0.2-0.4 ; 0.4-0.6 ; 0.6-0.8$ and $>0.8 \mathrm{~mm}$ (De Conti et al., 2018).

\subsection{Statistical analysis}

The data were tested for normality and homogeneity of variance through the Lilliefors and Shapiro-Wilk tests. Afterwards, the data were submitted to analysis of variance through SISVAR software, version 4.0 (Ferreira, 2011). The chemical attributes of the soil solution, plant growth, morphological and nutritional parameters were compared between Cu doses in the same cropping treatment and between cropping treatments at the same $\mathrm{Cu}$ dose. The means were grouped by the Scott-Knott test at $5 \%$.

\section{Results}

\subsection{Soil solution}

The exogenous addition of $\mathrm{Cu}$ in soil increased $\mathrm{Cu}$ content in soil solution, regardless of the cropping treatment, at the two samplings (Table 2). The highest $\mathrm{Cu}$ contents were detected in the soil solutions sampled in Grapevine + Axonopus affinis at dose 80 compared to the other cropping treatments at the 2nd sampling. The addition of dose 80 led to a decrease in soil solution $\mathrm{pH}$ at the two samplings, but pH did not differ at dose 40 in monocropping. At 
the 2nd sampling, soil solutions sampled in intercropping (both Grapevine + Paspalum plicatulum and Grapevine + Axonopus affinis) (Table 2) exhibited higher $\mathrm{pH}$ values than the one sampled in monocropping at dose 0 and dose 40 .

Dissolved organic carbon (DOC) concentration decreased at dose 80 compared to dose 0 in all the cropping treatments at the 2nd sampling (Table 2). Among the cropping treatments, Grapevine + Paspalum plicatulum promoted the highest DOC concentration, except for dose 0 and dose 80 at the 2 nd sampling.

The chemical species of $\mathrm{Cu}$ predominating in the soil solution at all doses and cropping treatments were $\mathrm{Cu}^{+2}$ and $\mathrm{Cu}$-DOC, together comprising between 93 and $99 \%$ of the soluble $\mathrm{Cu}$ (Fig. 2). $\mathrm{Cu}^{+2}$ was predominant in all the treatments at the 1st sampling. At this sampling, the percentage of $\mathrm{Cu}^{+2}$ increased with increasing $\mathrm{Cu}$ dose in Grapevine + Paspalum plicatulum, while the percentage was similar among $\mathrm{Cu}$ doses in the cropping treatments. At the 2nd sampling, $\mathrm{Cu}^{+2}$ increased with increasing $\mathrm{Cu}$ doses applied to the soil in all the cropping treatments. The highest percentages of $\mathrm{Cu}^{+2}$ at the 2 nd sampling were found in monocropping at all the $\mathrm{Cu}$ doses.

The reduction in the percentage of $\mathrm{Cu}^{+2}$ at dose 0 and dose 40 throughout cultivation was accompanied by the increase in the percentage of Cu-DOC (Fig. 2). Cu-DOC was predominant at the 2nd sampling in the solution of the soils under intercropping at dose 0 and dose 40, while $\mathrm{Cu}^{+2}$ predominated in monocropping. At the 2nd sampling, Grapevine + Paspalum plicatulum increased the proportion of Cu-DOC in approximately 84, 131 and $41 \%$ and Grapevine + Axonopus affinis in approximately 65, 81 and $47 \%$ in comparison to monocropping at doses 0,40 and 80 , respectively. Other species, including $\mathrm{CuOH}^{+}, \mathrm{CuSO}_{4(\mathrm{aq})}, \mathrm{CuNO}_{3}^{+}, \mathrm{CuHPO}_{4(\mathrm{aq}) \text {, }}$ $\mathrm{CuCl}^{+}$and $\mathrm{Cu}(\mathrm{OH})_{2(\mathrm{aq})}$ were present in small amounts in the soil solution.

\subsection{Plant growth}

Excess $\mathrm{Cu}$ impaired grapevine plant growth. This was diagnosed by reduced leaf and stem dry matter (DM) yield (Fig. 3a and b). This reduction in growth was alleviated when the plants were intercropped with the grass species: at dose 40, intercropping increased leaf and stem DM yield by 362 and 523\% in Grapevine + Paspalum plicatulum, respectively, and by 262 and $346 \%$ in
Grapevine + Axonopus affinis, respectively, compared to monocropping. At dose 40, Grapevine + Paspalum plicatulum also presented higher stem and leaf DM yield compared to the other cropping treatments (Fig. 3a and b). There was no significant difference in leaf and stem DM yield among the cropping treatments at dose 80 , but these yields were lower in intercropping at dose 0 and dose 40. $\mathrm{Cu}$ addition and cropping treatments did not significantly change root DM yield of young grapevines (Fig. 3c).

\subsection{Nutrient content and root morphology}

Excess $\mathrm{Cu}$ affected the nutritional status of the grapevines, particularly P, Fe and Mn contents in all plant tissues (Table 3). Leaf phosphorus content reduced in grapevines grown in monocropping at dose 80 , while it did not differ from dose 0 in intercropping. Also, stem P content was the lowest at dose 80 in all the cropping treatments, which was also found in roots of grapevines in intercropping (Table 3). At dose 40, P root content was 52 and 38\% higher in the Grapevine + Paspalum plicatulum and Grapevine + Axonopus affinis treatments compared to monocropping, respectively. At dose 80 , there was no difference in P contents among the cropping treatments in the three tissues evaluated in this study.

The highest $\mathrm{Cu}$ content in leaf, stem and root tissue was found at dose 40 and 80, while the lowest Cu contents in all the plant tissues were found at dose 0 (Table 3 ). Intercropping grapevines with Paspalum plicatulum and Axonopus affinis reduced stem Cu contents at dose 0 and dose 40. In leaves and roots, no regular pattern of response was observed. In fact, we found an opposite trend: root $\mathrm{Cu}$ content was higher in intercropping compared monocropping at dose 40 and dose 80 (Table 3).

Leaf and stem Fe contents were not affected by Cu dose, but leaf Fe content was affected by cropping treatment. In fact, grapevines grown in intercropping exhibited lower leaf Fe content than those in monocropping. No differences were found in stem Fe contents among $\mathrm{Cu}$ doses and cropping treatments. At dose 40 e 80, grapevines grown in intercropping showed higher root Fe contents in comparison to monocropping (Table 3).

Grapevine leaves, stems and roots in all cropping treatments exhibited an increase in $\mathrm{Mn}$ content at the highest $\mathrm{Cu}$ dose (Table 3). In most cases, grapevines grown in monocropping

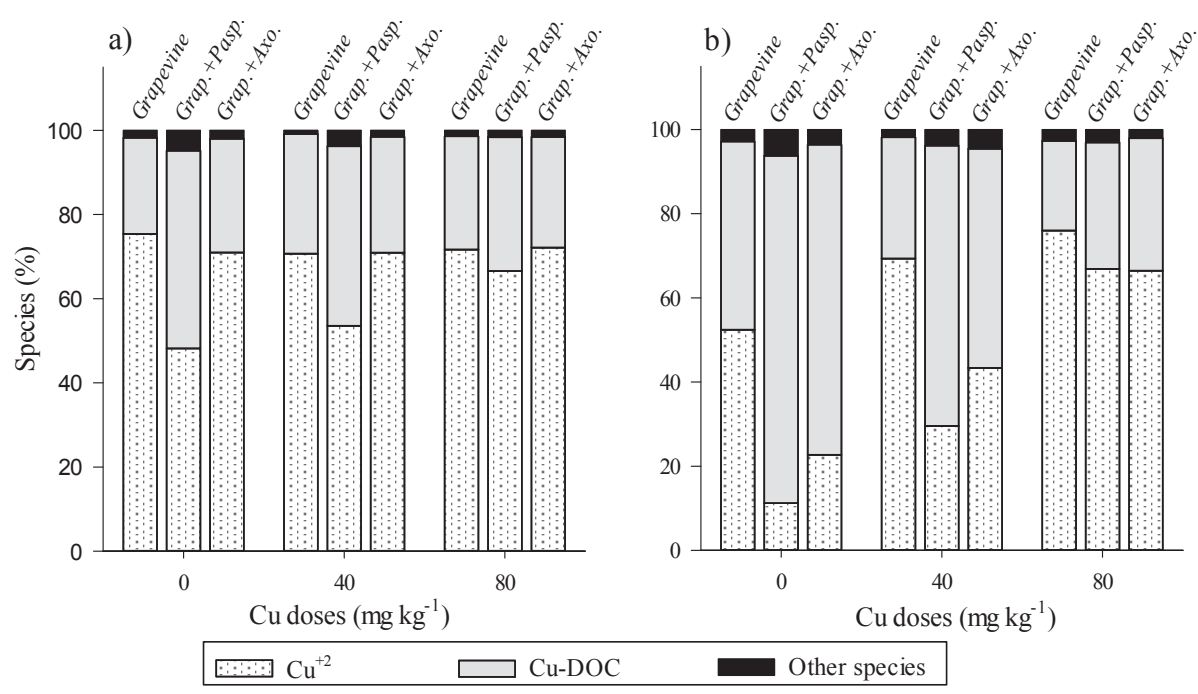

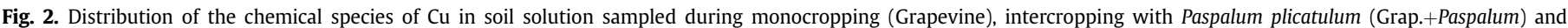

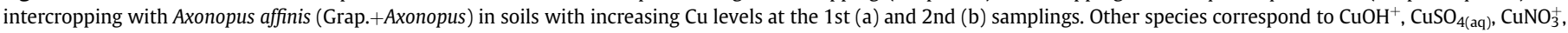
$\mathrm{CuHPO}_{4(\mathrm{aq})}, \mathrm{CuCl}^{+}$and $\mathrm{Cu}(\mathrm{OH})_{2(\mathrm{aq})}$. 

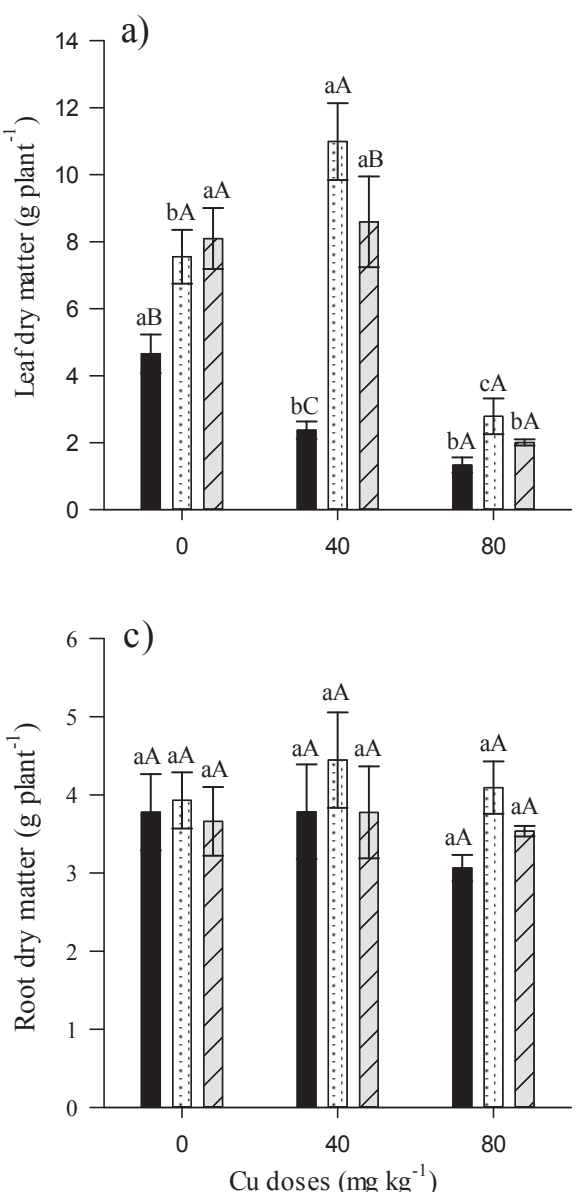
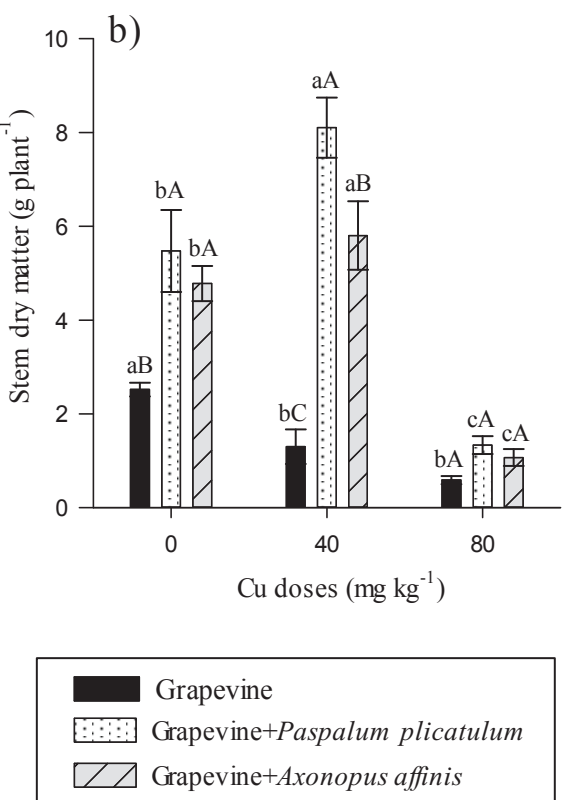

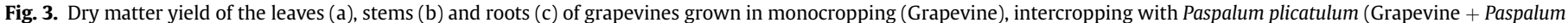

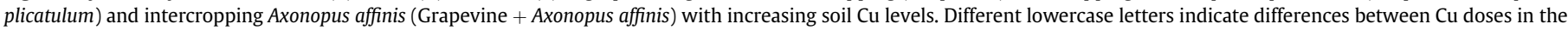
same cropping treatment and different uppercase letters indicate differences between the cropping treatments at the same Cu dose by Scott-Knott test ( $\mathrm{p}<0.05$ ).

exhibited higher Mn contents in plant tissues than in intercropping. Mn content increased by 130 and 28\% in leaves, 254 and 106\% in stems, and 101 and $55 \%$ in roots in monocropping compared to Grapevine + Paspalum plicatulum and Grapevine + Axonopus affinis at dose 80 , respectively.

Root morphology was affected by excess Cu contents, which was confirmed by reduced length and surface area at dose 80 in all the cropping treatments (Fig. 4a and b). At dose 40, root length and surface area of grapevines grown in intercropping were not depressed under $40 \mathrm{mg} \mathrm{Cu} \mathrm{kg}{ }^{-1}$, where the highest values were found. Average root diameter increased with $\mathrm{Cu}$ doses in all the cropping treatments (Fig. 4c). The highest root volume of grapevines grown in monocropping was found at dose 0 . In Grapevine + Paspalum plicatulum, the highest root volume was found at dose 40 (Fig. 4d). The intercropping of both native grasses at dose 40 promoted an increase in root volume compared to monocropping.

Copper toxicity changed the distribution of the root system in the different diameter classes, increasing the percentage of roots with a diameter greater than $0.8 \mathrm{~mm}$ and reducing the percentage of roots with diameter between 0.2 and $0.4 \mathrm{~mm}$ (Fig. 4e). In Grapevine + Paspalum plicatulum, these changes were significant only at dose 80 (Fig. 4e). At dose 40 , roots with diameter greater than $0.8 \mathrm{~mm}$ comprised $39 \%$ of the root system of grapevines grown in monocropping, 27\% in Grapevine + Paspalum plicatulum and 33\% in Grapevine + Axonopus affinis. The ratio of finer roots $(0-0.2 \mathrm{~mm})$ reduced with increasing $\mathrm{Cu}$ dose in monocropping, while a reduction was restricted to dose 80 in intercropping. The ratio of the roots between $0.4-0.6$ and $0.6-0.8 \mathrm{~mm}$ were little affected by the addition of $\mathrm{Cu}$ in all the cropping treatments.

\section{Discussion}

As expected, the addition of $\mathrm{Cu}$ caused a sharp increase in the soluble $\mathrm{Cu}$ pool in the soil, which was substantial at the dose of $80 \mathrm{mg} \mathrm{Cu} \mathrm{kg}{ }^{-1}$. This result indicates that mineral and organic $\mathrm{Cu}$ adsorption sites were saturated by dose 40 and 80 . This was also described by Girotto et al. (2014) and De Conti et al. (2016). The increase in $\mathrm{Cu}$ content in the soil solution shows the low sorption capacity of sandy soils and the high toxicity potential for plants. This soluble pool was the source mostly used by the roots in the nutrient acquisition process (Marschner, 2011). Moreover, from an environmental and aquifer perspective, the extent of this fraction could represent a serious concern for its mobility through surface runoff and leaching, especially when in excess (Babcsányi et al., 2016).

The plant growing period decreased $\mathrm{Cu}^{2+}$ fraction in the soil solution at the 2 nd sampling, although grapevines grown in monocropping were restricted to dose 0 . On the other hand, $\mathrm{Cu}^{2+}$ reduction at the 2 nd sampling was significant at doses 0 and 40 in intercropping (Fig. 2). This effect can be reasonably ascribed to increased $\mathrm{pH}$ in the soil solution and DOC concentration at dose 40. Root acquisition and accumulation in plant tissues may also have contributed to changes in the chemical attributes of the soil 
Table 3

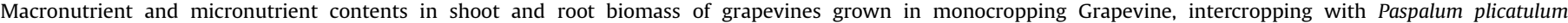
(Grap.+Paspalum) and intercropping with Axonopus affinis (Grap.+Axonopus) with increasing soil Cu levels.

\begin{tabular}{|c|c|c|c|c|}
\hline \multirow[t]{2}{*}{ Nutrient } & \multirow[t]{2}{*}{ Cu doses } & \multicolumn{3}{|c|}{ Cropping treatments } \\
\hline & & Grapevine & Grapevine + Paspalum & Grapevine + Axonopus \\
\hline & $\left(\mathrm{mg} \mathrm{kg}^{-1}\right)$ & Leaf & & \\
\hline \multirow[t]{3}{*}{$\mathrm{P}\left(\mathrm{g} \mathrm{kg}^{-1}\right)$} & 0 & $2.01 \mathrm{aA}^{1}$ & $1.40 \mathrm{aB}$ & $1.40 \mathrm{bB}$ \\
\hline & 40 & $2.12 \mathrm{aA}$ & $1.56 \mathrm{aB}$ & $1.74 \mathrm{aB}$ \\
\hline & 80 & $1.22 \mathrm{bA}$ & $1.24 \mathrm{aA}$ & $1.38 \mathrm{bA}$ \\
\hline \multirow{3}{*}{$\mathrm{Cu}\left(\mathrm{mg} \mathrm{kg}^{-1}\right)$} & 0 & $9.07 \mathrm{cA}$ & $6.99 \mathrm{bB}$ & $8.43 \mathrm{cA}$ \\
\hline & 40 & $14.07 \mathrm{aA}$ & $12.55 \mathrm{aB}$ & $14.83 \mathrm{aA}$ \\
\hline & 80 & $10.95 \mathrm{bA}$ & $11.71 \mathrm{aA}$ & $12.55 \mathrm{bA}$ \\
\hline \multirow[t]{3}{*}{$\mathrm{Fe}\left(\mathrm{mg} \mathrm{kg}^{-1}\right)$} & 0 & $82.44 \mathrm{aA}$ & $45.60 \mathrm{aB}$ & $49.48 \mathrm{aB}$ \\
\hline & 40 & $71.80 \mathrm{aA}$ & $50.88 \mathrm{aB}$ & $52.68 \mathrm{aB}$ \\
\hline & 80 & $82.04 \mathrm{aA}$ & $53.16 \mathrm{aB}$ & $50.28 \mathrm{aB}$ \\
\hline \multirow[t]{4}{*}{$\operatorname{Mn}\left(\mathrm{mg} \mathrm{kg}^{-1}\right)$} & 0 & $106.83 \mathrm{cA}$ & $98.27 \mathrm{bA}$ & $88.23 \mathrm{bA}$ \\
\hline & 40 & 244.99 bA & $106.99 \mathrm{bB}$ & $112.83 \mathrm{bB}$ \\
\hline & 80 & $580.75 \mathrm{aA}$ & $251.95 \mathrm{aC}$ & $454.43 \mathrm{aB}$ \\
\hline & & Stem & & \\
\hline \multirow[t]{3}{*}{$\mathrm{P}\left(\mathrm{g} \mathrm{kg}^{-1}\right)$} & 0 & $1.19 \mathrm{aA}$ & $1.05 \mathrm{aA}$ & $1.08 \mathrm{aA}$ \\
\hline & 40 & $1.04 \mathrm{bA}$ & $1.07 \mathrm{aA}$ & $1.19 \mathrm{aA}$ \\
\hline & 80 & $0.55 \mathrm{cA}$ & $0.59 \mathrm{bA}$ & $0.65 \mathrm{bA}$ \\
\hline \multirow[t]{3}{*}{$\mathrm{Cu}\left(\mathrm{mg} \mathrm{kg}^{-1}\right)$} & 0 & $7.83 \mathrm{bA}$ & $5.19 \mathrm{bB}$ & $5.87 \mathrm{cB}$ \\
\hline & 40 & $10.95 \mathrm{aA}$ & $8.35 \mathrm{aB}$ & $9.19 \mathrm{aB}$ \\
\hline & 80 & $8.51 \mathrm{bA}$ & $7.39 \mathrm{aA}$ & $7.51 \mathrm{bA}$ \\
\hline \multirow[t]{3}{*}{$\mathrm{Fe}\left(\mathrm{mg} \mathrm{kg}^{-1}\right)$} & 0 & $35.83 \mathrm{aA}$ & $27.71 \mathrm{aA}$ & $34.23 \mathrm{aA}$ \\
\hline & 40 & $33.99 \mathrm{aA}$ & $30.07 \mathrm{aA}$ & $31.55 \mathrm{aA}$ \\
\hline & 80 & $34.35 \mathrm{aA}$ & $32.79 \mathrm{aA}$ & $30.11 \mathrm{aA}$ \\
\hline \multirow[t]{4}{*}{$\operatorname{Mn}\left(\mathrm{mg} \mathrm{kg}^{-1}\right)$} & 0 & $35.97 \mathrm{cA}$ & $54.05 \mathrm{bA}$ & $37.77 \mathrm{bA}$ \\
\hline & 40 & $62.33 \mathrm{bA}$ & $63.65 \mathrm{bA}$ & $54.81 \mathrm{bA}$ \\
\hline & 80 & $309.37 \mathrm{aA}$ & $87.29 \mathrm{aC}$ & $150.57 \mathrm{aB}$ \\
\hline & & Root & & \\
\hline \multirow[t]{3}{*}{$\mathrm{P}\left(\mathrm{g} \mathrm{kg}^{-1}\right)$} & 0 & $1.06 \mathrm{aA}$ & $1.03 \mathrm{bA}$ & $1.07 \mathrm{aA}$ \\
\hline & 40 & $0.79 \mathrm{aC}$ & $1.20 \mathrm{aA}$ & $1.09 \mathrm{aB}$ \\
\hline & 80 & $0.69 \mathrm{aA}$ & $0.69 \mathrm{cA}$ & $0.76 \mathrm{bA}$ \\
\hline \multirow[t]{3}{*}{$\mathrm{Cu}\left(\mathrm{mg} \mathrm{kg}^{-1}\right)$} & 0 & $13.72 \mathrm{cA}$ & $16.24 \mathrm{cA}$ & $19.08 \mathrm{cA}$ \\
\hline & 40 & $78.24 \mathrm{bB}$ & $120.32 \mathrm{bA}$ & $108.80 \mathrm{bA}$ \\
\hline & 80 & $125.44 \mathrm{aC}$ & $165.64 \mathrm{aB}$ & $200.12 \mathrm{aA}$ \\
\hline \multirow[t]{3}{*}{$\mathrm{Fe}\left(\mathrm{mg} \mathrm{kg}^{-1}\right)$} & 0 & $417.96 \mathrm{aA}$ & 243.72 bB & $259.24 \mathrm{aB}$ \\
\hline & 40 & 152.32 bC & $290.32 \mathrm{aA}$ & 209.96 bB \\
\hline & 80 & $114.64 \mathrm{bB}$ & 227.48 bA & 201.40 bA \\
\hline \multirow[t]{3}{*}{$\operatorname{Mn}\left(\mathrm{mg} \mathrm{kg}^{-1}\right)$} & 0 & $43.24 \mathrm{cA}$ & $48.60 \mathrm{cA}$ & $47.24 \mathrm{bA}$ \\
\hline & 40 & $68.36 \mathrm{bA}$ & $73.88 \mathrm{bA}$ & 49.72 bB \\
\hline & 80 & $213.80 \mathrm{aA}$ & $106.64 \mathrm{aC}$ & $137.88 \mathrm{aB}$ \\
\hline
\end{tabular}

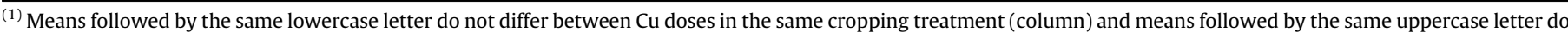
not differ between the cropping treatments at the same $\mathrm{Cu}$ dose (row) by the Scott-Knott test $(\mathrm{p}<0.05)$.

solution, reducing the $\mathrm{Cu}^{2+}$ fraction at the 2 nd sampling (Table 3 ) (De Conti et al., 2018).

The morphological changes of the root systems, although having similar values of dry matter yield (Fig. 3), clearly indicate the greater sensitivity of these morphological parameters to evaluate $\mathrm{Cu}$ toxicity in short-term experiments with grapevines. The accumulation of absorbed $\mathrm{Cu}$ predominated in the roots, with small translocation to shoots (Table 3 ). $\mathrm{Cu}$ accumulation in the roots is considered a tolerance mechanism to prevent and/or reduce excess translocation of $\mathrm{Cu}$ to the shoots, where it would cause greater damage to important physiological processes of the plant (Juang et al., 2012; Girotto et al., 2016). However, once inside the plant tissues, $\mathrm{Cu}$ complexation with carboxylic acids (citric, malic and oxalic) and the compartmentalization of the complexes in vacuoles have been described as components of the complex tolerance response to metal toxicity (Dresler et al., 2014). In this regard, an important role has also been attributed to $\mathrm{Cu}$ complexation by phosphate ions (Arriagada et al., 2009).

The addition of doses 40 e 80 in soil caused a reduction in $\mathrm{P}$ content in the different grapevine organs, which varied among the cropping treatments. This effect on $\mathrm{P}$ contents in grapevine plants is not entirely new. This has also been described in different conditions by Toselli et al. (2009) and Cambrollé et al. (2015). On the other hand, Mn contents in root tissues increased with increasing $\mathrm{Cu}$ availability (Table 3 ). These nutritional imbalances seem to corroborate the idea of the effect of $\mathrm{Cu}$ toxicity on membrane integrity and on the functionality of the membrane transporters, which in turn impact the selectivity of the nutrient acquisition process (Cambrollé et al., 2015). Although Mn is an essential element (important for several processes such as photosynthesis, oxidation-reduction reactions, electron transport as well as being a component of enzymes) (Marschner, 2011), leaf content over $400 \mathrm{mg} \mathrm{Mn} \mathrm{kg}^{-1}$ impairs the growth of most plants (KabataPendias, 2011). Moreover, because leaf Mn contents in this study were close to or above levels considered excessive $\left(400 \mathrm{mg} \mathrm{kg}^{-1}\right)$ in plants grown in soil treated with $80 \mathrm{mg} \mathrm{Cu} \mathrm{kg}^{-1}$, the phenomenon surely represents a further aspect of concern, especially in cases of highly Cu-contaminated soils. The increase in Mn availability was most likely due to the exchange with $\mathrm{Cu}$ in sorption sites of the soil colloids, increasing content in the soil solution and uptake by the grapevines (Sposito, 1989).

$\mathrm{Cu}$ contents in leaves and stems were little affected by $\mathrm{Cu}$ doses and cropping treatments (Table 3 ) in spite of the severe depressive effect exerted on dry matter accumulation in these two tissues 
a)

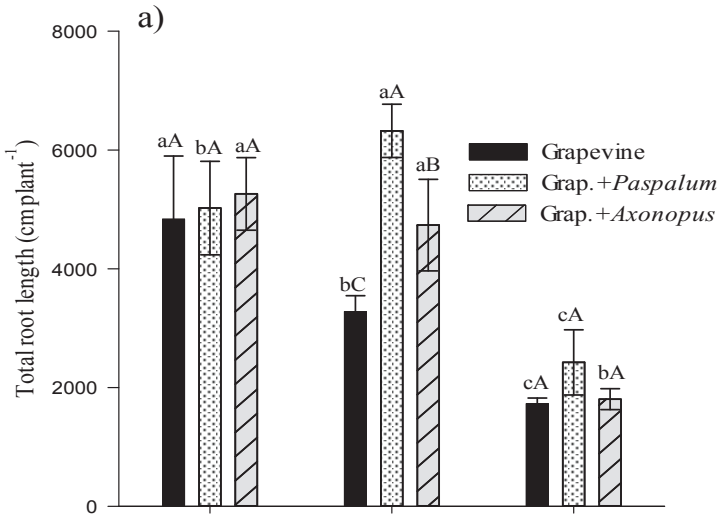

c)

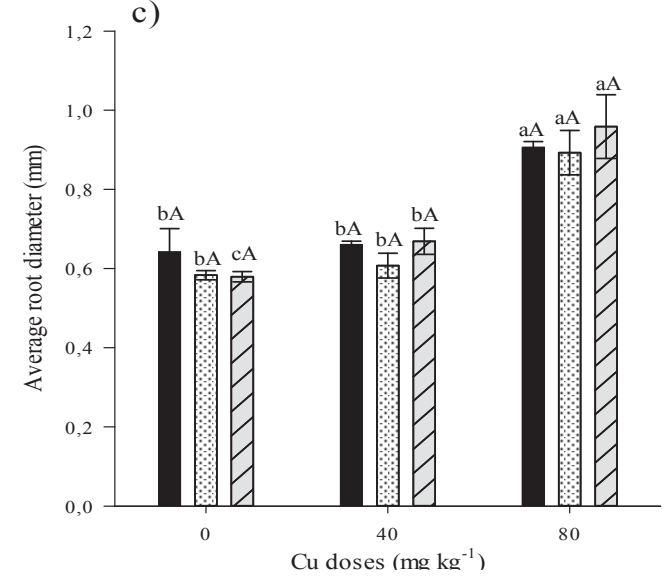

b)

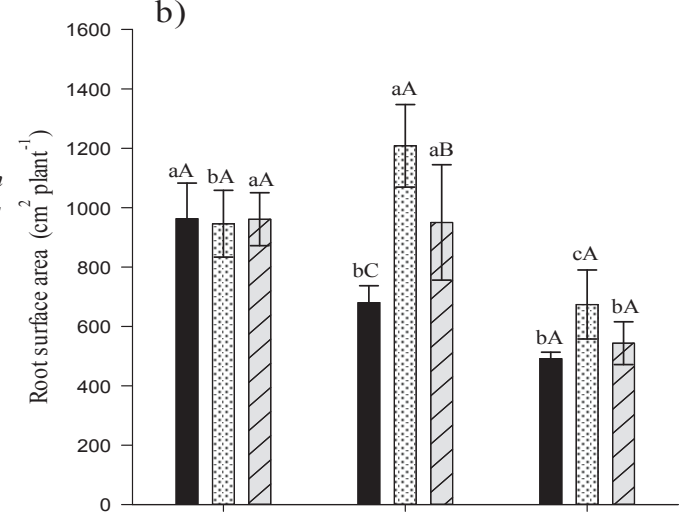

d)

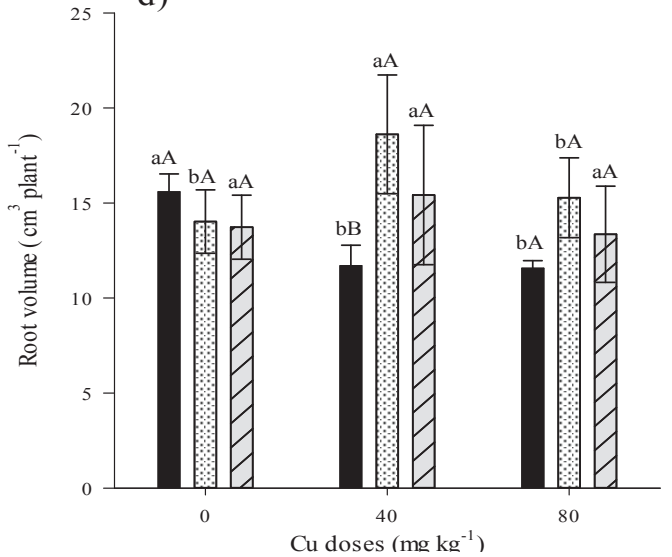

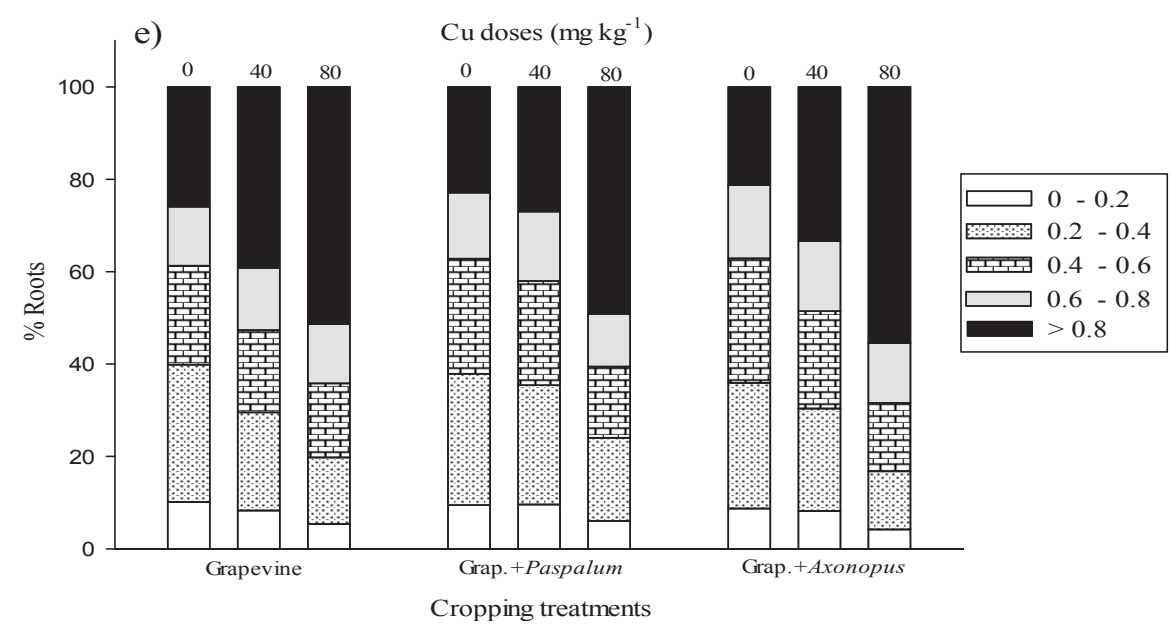

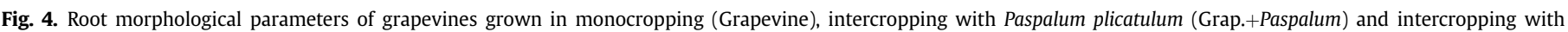

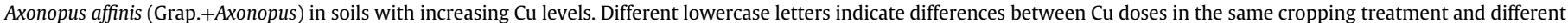
uppercase letters indicate differences between the cropping treatments at the same Cu dose by Scott-Knott test $(p<0.05)$.

(Fig. 3). This indicates that grapevines have efficient mechanisms in the root system to prevent or reduce translocation of excess $\mathrm{Cu}$ to shoots (Yruela, 2005; Cambrollé et al., 2015; Oustriere et al., 2016). Overall, the results of the grapevines grown in monocropping confirm $\mathrm{Cu}$ toxicity of exogenous origin in viticulture, even at moderate levels of contamination (dose 40) in sandy soils with low organic matter content. The results presented here show advantages of intercropping in cases of Cu toxicity. Indeed, with respect to the development of the young grapevines, the negative impact caused by Cu toxicity (especially on leaf and stem dry matter) were slightly mitigated by intercropping with Axonopus affinis or Paspalum plicatulum plants (Fig. 3), and were especially effective in soil treated with $40 \mathrm{mg} \mathrm{Cu} \mathrm{kg}^{-1}$. Contrarily, the efficiency of this recovery was reduced when grapevines were grown in soil contaminated with $80 \mathrm{mg} \mathrm{Cu} \mathrm{kg}^{-1}$. In fact, leaf and stem dry matter accumulated by these plants under $80 \mathrm{mg} \mathrm{Cu} \mathrm{kg}^{-1}$ were less than half of those of the control plants (monocropping in untreated soil). This result clearly indicates the need to integrate other remediation 
strategies to intercropping in cases of severe soil Cu contamination to guarantee adequate development of young grapevines (Fuksova et al., 2010; Oustriere et al., 2016).

The effects of intercropping are most likely attributed to phenomena occurring at soil level, in particular, the space shared by the two plant species and where they can mutually interact (rhizosphere). In this respect, it is interesting to note that the distribution of soluble $\mathrm{Cu}$ species during grapevine cultivation in intercropped approach with the native grasses changed in favors $\mathrm{Cu}-\mathrm{DOC}$ at the expense of $\mathrm{Cu}^{2+}$ (Fig. 2). Particularly, Grapevine + Paspalum plicatulum promoted the greatest reductions in $\mathrm{Cu}^{2+}$, except at dose 80. Considering that ionic $\mathrm{Cu}^{2+}$ is the form preferentially absorbed by plants and microorganisms (McBride, 1994; Martínez and McBride, 1999), the consequences of increased $\mathrm{Cu}$ chemical species complexed (Cu-DOC) in the soil solution is reduced bioavailability and potential toxicity to grapevines. In addition to concentration, it should be stressed that plants can also modify DOC composition through root exudation of soluble organic compounds, such as organic acids and phenolic compounds, as described for malic acid in response to high $\mathrm{Cu}$ levels (Nian et al., 2002), decreasing the phytotoxic potential of the contaminants (Kim et al., 2010).

The metal complexing property of these compounds and their release into the rhizosphere has been also described as an attempt by the plants to assure a balanced uptake in cases of nutrient shortage or to limit the availability of toxic elements (Jones, 1998; Pallarés et al., 2005; Malta et al., 2016). Particularly in the case of intercropping, the phenomenon could mean that the inefficient plant species can take advantage of the adaptive response of the efficient one, as described for the intercropping of Morus alba $\mathrm{L}$ and Pteris vittata $L$ in arsenic contaminated soil (Wan et al., 2017) or for citrus plants and cover crop species grown in soil with Fe shortage (Cesco et al., 2006). Moreover, the interaction of $\mathrm{Cu}$ with the functional groups of DOC was considered responsible for decreased $\mathrm{Cu}^{2+}$ availability in soils treated with biochar and compost amendments (Oustriere et al., 2016).

In the root systems it is interesting to note the higher accumulation of $\mathrm{Cu}$ in grapevines grown in intercropping (Table 3). In fact, it is reasonable to assume that the metal complexation/immobilization processes under these conditions are particularly pronounced at the root surface of both plant species, also leading to an enrichment of the root extraplasmatic pool of these $\mathrm{Cu}$ forms $(\mathrm{Cu}-$ complexes). However, it is evident that the whole process limits free $\mathrm{Cu}^{2+}$ fraction available for root acquisition, which is particularly interesting and useful for grapevine roots in Cu-contaminated soils. In addition, the enhanced development of these roots in intercropping (Fig. 4) could be part of a plant strategy to preferentially colonize soil zones less contaminated by $\mathrm{Cu}$ such as the rhizosphere of roots of plant species (e.g., Axonopus affinis and Paspalum plicatulum) resistant to toxic elements (Pallarés et al., 2005).

The root grows towards less toxic patches of soil (Bochicchio et al., 2015) and research has reported root intermingling between different plant species when under limited nutrient availability (Cesco et al., 2006). However, it should be stressed that the coexistence of two species in the same soil volume, as is the case in this study, may result in a series of competitive phenomena for nutrients and water between the roots of the two plant species. The extent of this may be more relevant in chemically poor soils and in regions with low rainfall.

The limited toxic effect of $\mathrm{Cu}$ on grapevines grown in intercropping with Axonopus affinis or Paspalum plicatulum can be partly attributed to the fact that the nutritional needs of two plant species rather than one has to be satisfied, thus limiting metal availability in the rhizosphere (De Conti et al., 2018). Nevertheless, regardless of these aspects, the results show that the release of organic carbon by the two native grasses surely contributes to the maintenance/ increase of soil organic matter content, which is of particularly relevant in sandy soils (Brunetto et al., 2014). In this regard, it is interesting to note the positive outcome of the use of native cover crop species on must quality of commercial vineyards under Mediterranean climate conditions (Muscas et al., 2017), regardless of the problem of $\mathrm{Cu}$ toxicity.

\section{Conclusions}

Intercropping young grapevines with Paspalum plicatulum and Axonopus affinis was efficient in promoting plant growth in soils with moderate and low levels of $\mathrm{Cu}$ contamination by reducing $\mathrm{Cu}$ bioavailability. The phytotoxic effects of $\mathrm{Cu}$ on root morphology in young grapevines were reduced by intercropping with these grasses at $40 \mathrm{mg} \mathrm{Cu} \mathrm{kg}{ }^{-1}$. This indicates that maintaining native grasses in young vineyards is an effective strategy for the phytoremediation of $\mathrm{Cu}$-contaminated soils and obtaining a grape production system with reduced interventions in the native environment, in addition to contributing to soil protection and nutrient cycling. However, even if attenuated in intercropping, excess Mn uptake and decreased $\mathrm{P}$ contents in grapevine tissues caused by $\mathrm{Cu}$ toxicity have to be considered for a balanced nutritional state of grapevines.

\section{Acknowledgments}

The authors would like to thank the National Council for Scientific and Technological Development (Conselho Nacional de Desenvolvimento Científico e Tecnológico - CNPq), the Coordination for the Improvement of Higher Education Personnel (Comissão de Aperfeiçoamento de Pessoal do Nível Superior - CAPES) and the Research Support Foundation of the state of Rio Grande do Sul (Fundação de Amparo a Pesquisa do Estado do Rio Grande do Sul FAPERGS) for the financial support.

\section{References}

Soil Survey Staff-SOIL TAXONOMY, 2006. A Basic System of Soil Classification for Making and Interpreting Soil Surveys, second ed. US Government Printing Office, Washington. (333p).

Ali, H., Khan, E., Sajad, M.A., 2013. Phytoremediation of heavy metals - concepts and applications. Chemosphere 91, 869-881.

Ambrosini, V.G., Rosa, D.J., Prado, J.P.C., Borghezan, M., Melo, G.W.B., Soares, C.R.F.S. Comin, J.J., Simão, D.G., Brunetto, G., 2015. Reduction of copper phytotoxicity by liming: a study of the root anatomy of young vines (Vitis labrusca L.). Plant Physiol. Biochem. 96, 270-280.

Arriagada, C, Aranda, E. Sampedro, I Garcia-Romera, I, Ocampo, JA, 2009. Contribution of the saprobic fungi Trametes versicolor and Trichoderma harzianum and the arbuscular mycorrhizal fungi Glomus deserticola and G. claroideum to arsenic tolerance of Eucalyptus globulus. Bioresour. Technol. 100, 6250-6257.

Babcsányi, I. Chabaux, F. Granet, M., Meite, F., Payraudeau, S., Duplay, J., Imfeld, G. 2016. Copper in soil fractions and runoff in a vineyard catchment: insights from copper stable/isotopes. Sci. Total Environ. 558, 154-162.

Baldi, E., Miotto, A., Ceretta, C.A., Quartieri, M., Sorrenti, G., Brunetto, G., Toselli, M., 2018. Soil-applied phosphorous is an effective tool to mitigate the toxicity of copper excess on grapevine grown in rhizobox. Sci. Hortic. 227, 102-111.

Bochicchio, R., Sofo, A., Terzano, R., Gattullo, C.E., Amato, M., Scopa, A., 2015. Root architecture and morphometric analysis of Arabidopsis thaliana grown in $\mathrm{Cd} / \mathrm{Cu} /$ Zn gradient agar dishes: a new screening technique for studying plant response to metals. Plant Physiol. Biochem. 91, 20-27.

Brasil, 2017. Ministério Do Meio Ambiente. Accessed in: 09 Oct. Online. Available in: http://www.mma.gov.br/biomas/pampa.

Brunetto, G., Miotto, A., Ceretta, C.A., Schmitt, D.E., Heinzen, J., Maraes, M.P., Canton, L., Tiecher, T.L., Comin, J.J., Girotto, E., 2014. Mobility of copper and zinc fractions in fungicide-amended vineyard sandy soils. Arch. Agron Soil Sci. 65, 609-624.

Brunetto, G., Melo, G.W.B., Terzano, R., Del Buono, D., Astolfi, S., Tomasi, N., Pii, Y., Mimmo, T., Cesco, S., 2016. Copper accumulation in vineyard soils: rhizosphere processes and agronomic practices to limit its toxicity. Chemosphere 162, 293-307.

Cambrollé, J., García, J.L., Figueroa, M.E., Cantos, M., 2015. Evaluating wild grapevine 
tolerance to copper toxicity. Chemosphere 120, 171-178.

Cesco, S., Rombolà, A.D., Tagliavini, M., Varanini, Z., Pinton, R., 2006. Phytosiderophores released by graminaceous species promote ${ }^{59} \mathrm{Fe}$-uptake in citrus. Plant Soil 287, 223-233.

Chaignon, V., Quesnoit, M., Hinsinger, P., 2009. Copper availability and bioavailability are controlled by rhizosphere $\mathrm{pH}$ in rape grown in an acidic $\mathrm{Cu}-$ contaminated soil. Environ. Pollut. 157, 3363-3369.

Chen, Y.T., Wang, Y., Yeh, K.C., 2017. Role of root exudates in metal acquisition and tolerance - current Opinion. Plant Biol. 39, 66-72.

De Conti, L., Ceretta, C.A., Ferreira, P.A.A., Lourenzi, C.R., Girotto, E., Lorensini, F., Tiecher, T.L., Marchezan, C., Anchieta, M.A., Brunetto, G., 2016. Soil solution concentrations and chemical species of copper and zinc in a soil with a history of pig slurry application and plant cultivation. Agric. Ecosyst. Environ. 216, $374-386$.

De Conti, L., Ceretta, C.A., Tiecher, T.L., Silva, L.O.S., Tassinari, A., Somavilla, L.M., Mimmo, T., Cesco, S., Brunetto, G., 2018. Growth and chemical changes in the rhizosphere of black oat (Avena strigosa) grown in soils contaminated with copper. Ecotox. Environ. Safe. 163, 19-27.

Dresler, S., Hanaka, A., Bednarek, W., Maksymiec, W., 2014. Accumulation of lowmolecular-weight organic acids in roots and leaf segments of Zea mays plants treated with cadmium and copper. Acta Physiol. Plant. 36, 1565-1575.

EMBRAPA-Empresa Brasileira de Pesquisa Agropecuária, 1997. CNPS: Manual de métodos de análise de solos. Embrapa Solos, Rio de Janeiro, p. 212p.

Ferreira, D.F., 2011. SISVAR: a computer statistical analysis system. Cienc. E Agrotecnol 35, 1039-1042.

Flores, S.S., Medeiros, R.M.V., 2013. Ruralidades na compreensão dos territórios do vinho e sua identidade, campo-território. Rev. Geogr. Agr. 8, 1-19.

Fuksova, Z., Szakova, J., Balik, J., Tlustos, P., 2010. Growth and metal uptake by plants grown inmono- and dual culture inmetal-contaminated soils. Soil Sediment Contam. 19, 188-203.

Girotto, E., Ceretta, C.A., Brunetto, G., Miotto, A., Tiecher, T.L., De Conti, L., Lourenzi, C.R., Lorensini, F., Gubiani, P.I., Silva, L.S., Nicoloso, F.T., 2014. Copper availability assessment of Cu-contaminated vineyard soils using black oat cultivation and chemical extractants. Environ. Monit. Assess. 186, 9051-9063.

Girotto, E., Ceretta, C.A., Rossato, L.V., Farias, J.G., Brunetto, G., Miotto, A., Tiecher, T.L., De Conti, L., Lourenzi, C.R., Schmatz, R., Giachini, A., Nicoloso, F.T., 2016. Biochemical changes in black oat (Avena strigosa schreb) cultivated in vineyard soils contaminated with copper. Plant Phys. Biochem. 103, 199-207.

Grimm, D.M., Azarraga, L.V., Carreira, L.A., Susetyo, W., 1991. Continuous multiligand distribution model used to predict the stability constant of copper(II) metal complexation with humic material from fluorescence quenching data. Environ. Sci. Technol. 25, 1427-1431.

Gustafsson, J.P., 2013. Visual Minteq. Online. Available from: http://www.lwr.kth.se/ english/oursoftwaer/Vminteq. verified 03 November 2016.

Hinsinger, P., Bengough, A.G., Vetterlein, D., Young, I., 2009. Rhizosphere: biophysics, biogeochemistry and ecological relevance. Plant Soil 321, 117-152.

Jones, D.L., 1998. Organic acids in the rhizosphere - a critical review. Plant Soil 205, 25-44.

Juang, K.W., Lee, Y.I., Lai, H.Y., Wang, C.H., Chen, B.C., 2012. Copper accumulation, translocation, and toxic effects in grapevine cuttings. Environ. Sci. Pollut. R. 19, 1315-1322.

Kabata-Pendias, A., 2011. Trace Elements in Soils and Plants. CRC Press, Boca Ratón, Florida.

Kim, K.-R., Owens, G., Naidu, R., Kwon, S.-L.K., 2010. Influence of plant roots on rhizosphere soil solution composition of long-term contaminated soils. Geoderma 155, 86-92.

Komárek, M., Cadková, E., Chrastný, V., Bordas, F., Bollinger, J.C., 2010. Contamination of vineyard soils with fungicides: a review of environmental and toxicological aspects. Environ. Int. 36, 138-151.

Kyte, L., Kleyn, J., Scoggins, H., Bridgen, M., 2013. Culture guide to selected plants. In: Culture Plants from Test Tubes. An Introduction to Micro-propagation, 4rd ed., pp. $221-223$.

Leguizamo, M.A.O., Gómez, W.D.F., Sarmiento, M.C.G., 2017. Native herbaceous plant species with potential use in phytoremediation of heavy metals, spotlight on wetlands - a review. Chemosphere 168, 1230-1247.

Malta, P.G., Silva, S.A., Ribeiro, C., Campos, N.V., Azevedo, A.A., 2016. Rudgea viburnoides (Rubiaceae) overcomes the low soil fertility of the Brazilian Cerrado and hyperaccumulates aluminum in cell walls and chloroplasts. Plant Soil 408 369-384.

Marschner, H., 2011. Mineral Nutrition of Higher Plants, third ed. Academic Press, London, p. 672.

Martínez, C.E., McBride, M.B., 1999. Dissolved and labile concentrations of Cd, Cu, $\mathrm{Pb}$ and $\mathrm{Zn}$ in aged ferrihydrite-organic matter systems. Environ. Sci. Technol. 33, 745-750.

McBride, M.B., 1994. Environmental Chemistry of Soils. Oxford University Press New York, p. 406

Mimmo, T., Del Buono, D., Terzano, R., Tomasi, N., Vigani, G., Crecchio, C., Pinton, R., Zocchi, G., Cesco, S., 2014. Rhizospheric organic compounds in the soilmicroorganism-plant system: their role in iron availability. Eur. J. Soil Sci. 65, 629-642.

Miotto, A., Ceretta, C.A., Brunetto, G., Nicoloso, F.T., Girotto, E., Farias, J.G. Tiecher, T.L., De Conti, L., Trentin, G., 2014. Copper uptake, accumulation and physiological changes in adult grapevines in response to excess copper in soil. Plant Soil 374, 593-610.

Miotto, A., Ceretta, C.A., Girotto, E., Trentin, G., Kaminski, J., De Conti, L., Moreno, T., Baldi, E., Brunetto, G., 2017. Copper accumulation and availability in sandy, acid, vineyard soils. Commun. Soil Sci. Plant Anal. 48, 1167-1183.

Murphy, J., Riley, J.P., 1962. A modified single solution method for determination of phosphate in natural waters. Anal. Chem. Acta 27, 31-36.

Muscas, E., Cocco, A., Mercenaro, L., Cabras, M., Lentini, A., Porqueddu, C., Nieddu, G., 2017. Effects of vineyard floor cover crops on grapevine vigor, yield, and fruit quality, and the development of the vine mealybug under a Mediterranean climate. Agric. Ecosyst. Environ. 237, 203-212.

Nian, H., Yang, Z.M., Ahn, S.J., Chen, Z.J., Matsumoto, H., 2002. A comparative study on the aluminium- and copper-induced organic acid exudation from wheat roots. Physiol. Plant. 116, 328-335.

Oustriere, N., Marchand, L., Galland, W.. Gabbon, L., Lottier, N., Motelica, M., Mench, M., 2016. Influence of biochars, compost and iron grit, alone and in combination, on copper solubility and phytotoxicity in a Cu-contaminated soil from a wood preservation site. Sci. Total Environ. 567, 816-825.

Pallarés, O.R., Barreta, E.J., Marasching, G.E., 2005. The South American campos ecosystem. In: Suttie, J.M., Reynolds, S.G., Batello, C. (Eds.), Grasslands of the World. FAO, Rome, pp. 171-219p.

Quadros, F.L.F., Trindade, J.P.P., Borba, M.A., 2009. Abordagem funcional da ecologia campestre como instrumento de pesquisa e apropriação do conhecimento pelos produtores rurais. In: Pillar, V.P., Müller, S.C., Castilhos, Z.M.S., Jacques, A.V.A. (Eds.), Campos Sulinos "conservação e uso sustentável da biodiversidade". Brasília-DF: Ministério do Meio Ambiente, pp. 206-213.

Sainger, P.A., Dhankhar, R., Sainger, M., Kaushik, A., Singh, R.P., 2011. Assessment of heavy metal tolerance in native plant species from soils contaminated with electroplating effluent. Ecotox. Environ. Safe. 74, 2284-2291.

Silva, L.S., Bohnen, H., 2001. Mineralização de palha de milho e adsorção de carbono, cálcio, magnésio e potássio em substratos com caulinita natural e goethita sintética. Rev. Bras. Ciênc. Solo 25, 289-296.

Smith, R.M., Martell, A.E., Motekaitis, R.J., 2003. NIST Critically Selected Stability Constants of Metal Complexes Database. NIST Standard Reference Database 46, Version 7.0. National Institute of Standard and Technology, Gaithersburg.

Sposito, G., 1989. The Chemistry of Soils. Oxford University Press, New York, p. 277.

Tiecher, T.L., Tiecher, T., Ceretta, C.A., Ferreira, P.A.A., Nicoloso, F.T., Soriani, H.H Tassinari, A., Paranhos, J.T., De Conti, L., Brunetto, G., 2016. Physiological and nutritional status of black oat (Avena strigosa Schreb.) grown in soil with interaction of high doses of copper and zinc. Plant Physiol. Biochem. 106, 253-263.

Toselli, M., Baldi, E., Marcolini, G., Malaguti, D., Quartieri, M., Sorrenti, G. Marangoni, B., 2009. Response of potted grapevines to increasing soil copper concentration. Aust. J. Grape Wine Res. 15, 85-92.

Wan, X., Lei, M., Chen, T., 2016. Cost-benefit calculation of phytoremediation technology for heavy-metal-contaminated soil. Sci. Total Environ. 563 796-802.

Wan, X., Lei, M., Chen, T., Yang, J., 2017. Intercropped Pteris vittata L. and Morus alba L. presents a safe utilization mode for arsenic-contaminated soil. Sci. Total Environ. 579, 1467-1475.

Yruela, I., 2005. Copper in plants. Braz. J. Plant Physiol. 171, 145-156. 